\title{
A Study on the Construction of Chinese Integrity Culture: Based on the Development Needs of the Country, Society, and Community
}

\author{
Hongyuan $\mathrm{Xu}^{1}$ Liansheng Yang ${ }^{1, *}$ \\ ${ }^{1}$ School of Marxism, Dalian University of Technology, Dalian, Liaoning 116024, China \\ "Corresponding author. Email: 84707554@163.com
}

\begin{abstract}
The social behavior model guided by high-quality development is the most important indicator to judge the ability and level of governance, which is also the value orientation of the highest level of national and social political practice. The value orientation of development has leading and guiding practical significance for the country, society and community. At the same time, it is precisely because of the development value of integrity culture to the country, society and community, and the practical needs of development that we need to strengthen the construction of integrity culture.
\end{abstract}

Keywords: the construction of integrity culture, the needs of development, country, society, community

\section{INTRODUCTION}

At present, China's economic and social development is in the transition period. The transition of mechanism and the adjustment of economic and social structure have a profound impact on the transformation of social values. During the period of social transformation, many social contradictions have accumulated. The "integrity crisis" is a typical example of social problems in the process of social transformation. With the development of economy and society, the problem of integrity has penetrated into whole society. The weakness of the individual's sense of integrity, the backwardness of the system of integrity construction and the lack of the credibility have greatly challenged the construction of a civilized and orderly modern society. However, the key of integrity construction lies in the construction of integrity culture. As the essence of modern culture, integrity culture is an inner spiritual experience in the process of people's communication and a moral and ethical relationship, which is also the result of the long-term hiding influence of the deep structure of society on social consciousness. Therefore, the construction of integrity culture is of great significance to develop the harmonious society.

The practice of integrity culture construction is rooted in the realistic background of the society and the development requirements of country, society and community. Under such a premise, the construction of integrity culture tends to be more systematic and hierarchical. In addition, the construction of integrity culture integrates various elements in the specific practice process, and creates the "integrity culture field" in the fields of country, society and community, which makes various positive elements interweave with each other. And under the interaction of rigidity and flexibility, coercion and enlightenment, external and internal, visibility and feeling, we can get the effect that individual measures can't achieve, and then affect individual social interaction, internalize the culture of integrity and integrity, and guide people's social practice behavior. Thus the systematic construction of integrity culture can effectively promote the positive operation of the country, society and community, and pass on the governance efficiency of integrity culture construction through effect transmission, so as to promote the governance of the country, society and community.

\section{THE PRACTICAL NEEDS OF NATIONAL DEVELOPMENT FOR THE CONSTRUCTION OF INTEGRITY CULTURE}

At the national level, the integrity contained in integrity culture is the basic moral standard of citizens and the foundation of economic development. Moreover, the cultural category of integrity culture is an important source of vitality, creativity and cohesion of a country, which has a special value function for the maintenance, consolidation and regulation of the national system.

The development of national economy depends on the construction of integrity culture. In the process of national economic development, the development potential of economic subjects is presented by the guidance of value orientation, and integrity culture as such a value orientation provides an important power for the development of national economy. As a result, integrity culture advocates the values of integrity, trustworthiness, fairness and justice, which makes integrity culture internalize from external variables to the endogenous power of economic development, liberating and developing productivity. In order to meet the high-quality development of the national economy, it is necessary to strengthen the construction of integrity and integrity culture. Therefore the development of national economy can provide an important material basis for the 
country, society and community development

The development of national politics relies on the construction of integrity culture. The political development is a process of political form transformation based on economic development, marked by the change of political system and with the reform and improvement of political system as its content. Besides, in the context of Marxism, socialist society, a social form based on a unified political foundation, is a harmonious state in which people's ideological understanding and values are fundamentally consistent with the political form. As a kind of ideology, integrity culture transmits the core values of socialism through its value function and operation mechanism, and leads the mainstream consciousness and values of the society in such a way. The breakthrough of China's political development must have the function of solving the three major problems of political identity, building social order and promoting the transformation of political culture at the same time [1]. Consequently, China's political development should deeply grasp the value of cultural construction for political identity, social order and cultural transformation, and systematically consider the promotion function of integrity culture for national political development.

\section{THE PRACTICAL NEEDS OF SOCIAL DEVELOPMENT FOR THE CONSTRUCTION OF INTEGRITY CULTURE}

In the process of social transformation, acquaintance society is transformed into modern society. Due to the decrease of social interaction of geography and consanguinity, it is more difficult for the public to find their own moral responsibility from the circle of acquaintances, which depends more on contracts to fulfill their moral responsibility. However, there are some limitations in this form of contract, which leads many people not to pay attention to the moral responsibility stipulated by the contract. The heterogeneity of modern society leads to the fuzzy order standard in modern society. Thus the moral and ethical norms and codes of conduct that the public used to abide by in social activities have lost their effectiveness, which leads to the increase of social instability and the entry of human beings into risk society. At the same time, China is in the period of social transformation, in which social construction and social development generally lag behind economic construction and development. Accordingly, we should strengthen the construction of integrity and integrity culture, timely adjust the communication mode of the public in the period of social transformation, adjust social contradictions and provide a harmonious and orderly social environment for social development.

The need of social development for the construction of integrity culture is based on the guiding function of the value core of integrity culture to the level of social development. Moreover, as a concrete embodiment of culture, integrity culture develops with society. As an individual, man is the core of the social structure. Among the elements of social development, man is also the only one factor with initiative. Meanwhile, the quality of social development depends on the moral and cultural quality of the subject. When the modernization of society has entered the era of knowledge-based economy, higher requirements have been put forward for the moral and cultural quality of the public. Therefore, it is of great significance for social development to strengthen the moral and cultural literacy of the public through the construction of social integrity culture. In addition, according to the development practice in the modern sense, it shows that the higher the degree of social development is, the more obvious the supporting role of culture is and the greater the contribution to social development is. As a result, integrity culture develops with social development, whose moral and cultural level runs through the whole process of social development, and integrates with social and economic development to produce core competitiveness.

\section{THE PRACTICAL NEEDS OF COMMUNITY DEVELOPMENT FOR THE CONSTRUCTION OF INTEGRITY CULTURE}

Community is the basic field of national and social development, whose development is the most basic level of development system. Social Progress Through Community Development, a report published by the United Nations in 1955, explains the definition and content of social development. It believes that community development is a process of creating economic and social progress conditions for the whole community through the active participation of community subjects and the initiative activities of community members as much as possible. And community development means the integration of two levels of strength, one is the opportunity and ability of cooperation, which is the ability of community members to adopt new life style based on the self-governing community identity; the other is the existing world-wide experience, which includes the use of technology and tools in the social and economic fields [2]. And the United Nations holds that the definition of community development relies on the initiative participation and cooperation of community members, which makes people's high-quality participation in community affairs become the purpose of community development, so as to improve the effective governance of grass-roots society. Accordingly, by strengthening the construction of community's integrity culture, we can enhance the awareness of community members, enhance the moral and cultural literacy, and then promote the further development of the community.

Community is the most basic community for the production and life of social members, which can meet people's indelible social emotions, and also an important field to cultivate resources for the development of the country and 
society. However, with the transformation of modernity and society, under the strong scour of risk society and mobile society, the cultural values and moral norms in the community field have been greatly impacted. In China, community is the link of social structure. But under the reform and opening up and the reform of market economy system, the cultural resources needed for community development are exhausted, and community develops slowly. At the same time, in the process of community development, there is a general trend of heterogeneity and individuation, while its publicity tends to be weak, which leads to the loss of public capital and the weakening of community identity. However, with the establishment and development of the market economy system, the negative effect of the attached moral value level is gradually enlarged. Thus community members pay more attention to their own interests and life, and public life is gradually away from people's daily life. Richard Sennett, a famous contemporary American sociologist, believes that the rise of individuals and the individualization of society brought about by the growth of modernity lead to the imbalance between private life and public life, and the field of private life continues to colonize the field of public life [3]. This kind of individual behavior orientation that lose publication makes the community members use irrational thinking to participate in community activities from the perspective of individuals. And the individual emotional thinking will affect the moral world of grass-roots society and the value evaluation of public affairs. Another meaning of community individuation is community's publicity dissolution. And publicity is the collective consciousness, value norm, behavior logic and expression system formed by individuals in the process of social activities and social communication with others. In the process of modernization transformation, the public life in the community is gradually individualized, and the willingness of community members to participate in community public affairs and public expression is reduced, and the community's publicity is gradually dispelled. Consequently, the dissolution of this publicity in the community will lead to social problems such as misconduct and moral nihility in the field of community seriously affect social development.

The other influence caused by the dissolution of community publicity is the loss of community social capital. The social capital in the community is the interpersonal network formed by the members of the community in the process of communication which provides the value consciousness and moral concepts such as trust, identity, belonging and responsibility, and constantly produces the value elements such as integrity, cooperation and public rationality needed by the community development in the social activities of the community. In a certain sense, the social capital structure of the community has become the dynamic factor and element of community development. And among those integrity is the psychological basis of community social capital. However, with the development trend of community individuation, the cultivation and development of community social capital is weakening. The values of social individuals tend to be diversified and the connection and isolation between people appear. And without the concept of communication, the concepts of unity, trust and autonomy will be meaningless, or at least will be reduced to symbols [4]. Also, without social interaction and participation in social activities, community members can't form a stable interpersonal network. People who are separated from public life think that they are surrounded by villains, so they will lack self-discipline of integrity [5].

After a series of social changes at the grassroots level, such as the enhancement of community individuation, the dissolution of publicity and the loss of community social capital, the community members' recognition of the community will be weakened and dissipated, the value function of the community will not be exerted, the community will decline, the structure system of the community will be collapsed, and the modernization process of community governance will be in trouble. However, the multiple difficulties of community development are caused by the erosion of multiple values and cultural concepts in the process of social transformation. This kind of multiple value and cultural concept leads to the cultural imbalance within the community and the disorder of the operation mechanism of community development. Thus we should rebuild the way of life of the community and realize the return of the community by strengthening the construction of moral culture. At the same time, to strengthen the construction of moral culture should be in line with the practice of community governance and take the development direction of governance moral culture in community. Coincidentally, the construction of integrity culture is in line with the development path of community governance.

\section{CONCLUSION AND DISCUSSION}

As the largest developing country, China's current fundamental task is still development. Development, the absolute principle, is the first priority. However, development should be an all-round economic, social, political, cultural and human development, which should also rely on economic, social, political, cultural and other aspects, run the concept of development, coordinate the forces at all levels, and promote the development of socialism with Chinese characteristics. In addition, integrity culture is the essential reflection of people's life, the standard form of various social relations, the moral culture form of the whole nation, and the important gene of the development. Therefore, we should strengthen the construction of integrity culture, improve the moral and cultural level of three aspects and regulate people's social interaction. Besides, we should take the construction of integrity culture as the tool of governance, and promote the modernization of governance by giving full play to the governance effect of integrity culture at different levels.

\section{REFERENCES}

[1] Zhang Mingjun, Chen Peng. Practical Preconditions and Creative Logic for the Political Development of 
Norton \& Company, 1992.

[4] Gerard Delanty. Modernity and Postmodernity: Knowledge, Power and the Self. SAGE Publications, 2000.

[5] Robert D. Putnam. Bowling Alone: The Collapse and Revival of American Community. Touchstone Books by Simon \& Schuster, 2001. 